\title{
Ursolic acid from Trailliaedoxa gracilis induces apoptosis in medullary thyroid carcinoma cells
}

\author{
VICTOR AGUIRIANO-MOSER ${ }^{1}$, BERNHARD SVEJDA ${ }^{1}$, ZENG-XIA LI $^{1,2}$, SONJA STURM $^{3}$, \\ HERMANN STUPPNER ${ }^{3}$, ELISABETH INGOLIC ${ }^{4}$, HARALD HÖGER ${ }^{5}$, VERONIKA SIEGL ${ }^{1}$, \\ NATHALIE MEIER-ALLARD ${ }^{1}$, ANTON SADJAK ${ }^{1}$ and ROSWITHA PFRAGNER ${ }^{1}$
}

\author{
${ }^{1}$ Department of Pathophysiology and Immunology, Center of Molecular Medicine, Medical University of Graz, \\ Graz A-8010, Austria; ${ }^{2}$ Department of Biochemistry \& Molecular Biology, Shanghai Medical School, Fudan University, \\ Shanghai 200433, P.R. China; ${ }^{3}$ Department of Pharmacognosy, Institute of Pharmacy, Center of Molecular Biosciences, \\ Leopold Franzens University of Innsbruck, Innsbruck A-6010; ${ }^{4}$ Core Unit of Biomedical Research, \\ Division of Laboratory Animal Science and Genetics, Medical University of Vienna, Himberg A-2325; \\ ${ }^{5}$ Research Institute for Electron Microscopy and Fine Structure Research, \\ University of Technology Graz, Graz A-8010, Austria
}

Received May 28, 2014; Accepted February 10, 2015

DOI: $10.3892 / \mathrm{mmr} .2015 .4053$

\begin{abstract}
Medullary thyroid carcinoma (MTC) originates from the C-cells of the thyroid and is not sensitive to radiation or chemotherapy. Therefore, surgical removal of the tumor tissue in its entirety is the only curative treatment for MTC. The present study aimed to examine the potential mechanisms of action of extracts of Trailliaedoxa gracilis (TG; WW Smith \& Forrest), a plant from the province of Sichuan, China, and of ursolic acid (UA), a pentacyclic triterpen present in $T G$, on the MTC-SK MTC cell line. A total of $13 T G$ fractions and UA were examined in vitro for their effects on cell morphology, cell number, proliferation and rates of apoptosis. Reverse transcription-quantitative polymerase chain reaction of nuclear factor- $\kappa \mathrm{B}$ essential modifier (NEMO) was performed to delineate the role of the apoptotic pathway following treatment with UA. $T G$ and UA were examined in vivo in xenotransplanted MTC-bearing severe combined immunodeficient mice. The $T G$ fractions exhibited antiproliferative effects, with inhibition of mitochondrial activity in the tumor cells at concentrations, which caused no impairment of the normal control cells. The apoptotic rates of the MTC-SK cells treated with the $T G$ fractions and UA were determined, in which no marked tumor inhibition was observed in the treated MTC-mice, and no change in the
\end{abstract}

Correspondence to: Professor Roswitha Pfragner, Department of Pathophysiology and Immunology, Center of Molecular Medicine, Medical University of Graz, 31a Heinrichstrasse, Graz A-8010, Austria E-mail: roswitha.pfragner@medunigraz.at

Key words: neuroendocrine tumors, medullary thyroid carcinoma, Trailliaedoxa gracilis, bioactive agents, ursolic acid, nuclear factor- $\kappa \mathrm{B}$ essential modulator, apoptosis expression of $N E M O$ was detected in the treated MTC-SK cells. The observation of early-onset activation of caspase 8 suggested that the responsible factor was linked to NEMO, an anti-apoptotic protein. However, no differences in the mRNA transcription levels of $N E M O$ were detected in MTC-SK cells treated with UA, suggesting that this protein was not associated with the signal transducer and activator of transcription 3 pathway.

\section{Introduction}

Medullary thyroid carcinoma (MTC) is a malignant neoplasm originating from the parafollicular C-cells of the thyroid, and accounts for $5-10 \%$ of all types of thyroid carcinoma. The majority of the tumors $(\sim 80 \%)$ are sporadic and predominantly solitary, whereas hereditary tumors appear as multiple nodules in the thyroid gland. In $50 \%$ of sporadic tumor cases, patients develop lymph node metastases prior to diagnosis, and $80 \%$ of these tumors exhibit a somatic missense point mutation, particularly in codon 918 of exon 16 of the RET-protooncogene (chromosome 10q11.2) (1).

Sporadic MTCs have a good prognosis when the lymph nodes are free of metastases. For existing lymph node metastases, the 10-year survival rate is between 40 and $50 \%$ (2). In sporadic MTCs, different schedules of treatment are considered, depending on the presence of metastases. Radical thyroidectomy with ablation of the cervical lymph nodes is the only curative treatment to date. Chemotherapy is ineffective for the treatment of MTC (2).

A mutation in the RET gene is the predominant cause of MTC. High expression levels of RET increase the expression of Fap-1, leading to a decrease in cluster of differentiation (CD) 95 cell death receptors. Since caspase 8 activation is mediated by the CD95 pathway, high expression levels of RET inhibit apoptosis in MTC (3). Sporadic MTC is not always a result of mutation in the RET gene, there have been previous 
studies demonstrating sporadic cases without this mutation, but with a mutation in $R A S$, or more specifically $H R A S$ (4).

A number of drugs used in chemotherapy have been developed from plant derivatives, including taxol. Our previous studies investigated the apoptotic effects of plants, including Stemona tuberosa Lour on MTC-SK cells (5), and Cautleya gracilis (Smith) Dandy and Trailliaedoxa gracilis (WW Smith \& Forrest) on neuroendocrine tumor (NET) cells of the midgut $(6,7)$, amongst several others $(8,9)$.

The present study examined extracts of Trailliaedoxa gracilis $(T G)$ and one component of these extracts, ursolic acid (UA) (10). $T G$ was originally characterized by Handel-Mazzetti in 1927 (11). TG is from the family Rubiaceae, and grows on rocky ground or in thickets on mountain slopes and in dry and warm valleys. In the Jinsha river valley close to Lijang (Yunnan, China), it has been found at $1,819 \mathrm{~mm}$ above sea level (12). UA, one component of $T G$, is a pentacyclic triterpene acid. It is known to inhibit the signal transducer and activator of transcription (STAT) 3 activation pathway and reduce the expression of matrix metalloproteinase 9 using a glucocorticoid receptor (13). It can also alter apoptotic pathways, reduce muscle atrophy and stimulate muscle hypertrophy in mice; UA is a weak aromatase inhibitor and is used as a cardioprotective compound (14).

The STAT3 Janus kinase is important for evading apoptosis and is essential for cell survival in a wide variety of types of human cancer. For example, the activation of STAT3 inhibits apoptosis and accelerates the progression of liver cancer (15). Suppression of STAT1 and STAT3 is accomplished by suppressors of cytokine signaling (SOCS)-1 and SOCS-3 (16), the expression of which are induced by nuclear factor $(\mathrm{NF})-\kappa \mathrm{B}$. Activation of $\mathrm{NF}-\kappa \mathrm{B}$ affects STAT signaling and, therefore, assists in apoptosis (17). NF- $\kappa \mathrm{B}$ also induces the expression of anti-apoptotic genes, however, the $\mathrm{NF}-\kappa \mathrm{B}$ response remains to be fully elucidated. $\mathrm{NF}-\kappa \mathrm{B}$ exists in the cytoplasm as an inactive form in the majority of cell types, and its activation is induced by a variety of extracellular ligands or genotoxic agents. As a dimer, NF- $\kappa \mathrm{B}$ is activated by a canonical and a non-canonical pathway. The canonical pathway stimulates $\mathrm{NF}-\kappa \mathrm{B}$ with cytokines, including tumor necrosis factor (TNF) $\alpha$, which causes a cascade of intracellular events and activates inhibitor of nuclear factor- $\kappa \mathrm{B}$ kinase $(\mathrm{IKK} \beta)$ with nuclear factor- $\kappa \mathrm{B}$ essential modifier (NEMO). This form of activation is induced rapidly, within minutes of stimulation (18). The non-canonical pathway is effective, has slower kinetics and does not require NEMO (18). When NEMO is highly expressed in cells due to the activation of $\mathrm{TNF} \alpha, \mathrm{NF}-\kappa \mathrm{B}$ inhibits the anti-apoptotic effects of STAT3, leading to cell death. By contrast, NEMO-deficient mice exhibit increased sensitivity to TNF-induced apoptosis, which contradicts the former (19). The anti-apoptotic effects of NEMO are independent of NF- $\mathrm{BB}$. NEMO binds to receptor interacting protein 1 (RIP1) and prevents the engagement of caspase- 8 prior to $\mathrm{NF}-\kappa \mathrm{B}$, mediating the induction of anti-apoptotic genes (20). A possible explanation for the contradictory effects of NEMO may be revealed in the expression levels of RIP-1 and NF- $\kappa$ B. In cells deficient of RIP1 and NF- $\kappa \mathrm{B}$, lower levels of cell death are observed in the absence of NEMO, suggesting that, under these conditions, NEMO is pro-apoptotic. It is possible that the lack of RIP1 causes NEMO to bind to another molecule, which acts as a competitive antagonist (20). By contrast, STAT3 regulates NEMO-like kinases by mediating its interaction with IL-6-stimulated TGF $\beta$ activated kinase 1 for the phosphorylation of STAT3 (Ser 727) (21), suggesting that STAT3 also affects the expression of NEMO.

The present study aimed to measure the growth inhibitory effects of $T G$ fractions on MTC-SK cells. Furthermore, fractions with high growth-inhibitory effects on the MTC-SK cells were assessed for apoptotic effects in vitro and in vivo. Following identification of the active agent in the plant fractions, the present study aimed to investigate the role of NEMO in two apoptotic pathways.

\section{Materials and methods}

Cell lines and cell culture. After obtaining written informed consent, cell lines were established in our laboratory. The MTC-SK cell line (1) was derived from lymph node metastasis of a 51-year-old central European woman. MTC-SK cells grow as multicellular spheroids in suspension and were maintained in Ham's F12 medium (Biowhittaker, Verviers, Belgium), supplemented with $10 \%$ fetal bovine serum (FBS; PAA Laboratories GmbH, Pasching, Austria). HF-SAR fibroblasts (22) were established from normal skin of a 3-year old male child, cultured in Eagle's minimal essential medium (PAA Laboratories GmbH), supplemented with $10 \%$ FBS, in which the cells grew adherently. The cell lines were incubated without antibiotics at $37^{\circ} \mathrm{C}, 5 \% \mathrm{CO}_{2}$ and $95 \%$ humidity and were Mycoplasma-free, confirmed with a MycoAlert ${ }^{\circledR}$ Mycoplasma Detection kit (Cambrex Bioscience, Rockland, ME, USA) and Hoechst 33258 (Sigma-Aldrich, Vienna, Austria). Hoechst stain $(50 \mu \mathrm{l})$ was added to $50 \mu \mathrm{l}$ cell suspension at a density of $2 \times 10^{5}$ (MTC-SK) and $1 \times 10^{5}$ (HF-SAR) cells/ml and incubated at room temperature for $5 \mathrm{~min}$. The study was approved by the ethics committee of the Medical University of Graz, Austria (18-182 ex 06/07).

Plant material. The $T G$ fractions were extracted at the Institute of Pharmacy and Pharmacognosy, Leopold-Franzens University of Innsbruck (Innsbruck, Austria) (10). The extraction and fractionation of Trailliaedoxa gracilis was performed, as described previously (7), resulting in the following fractions for use on the tumor cells: TG-E5-F16*, TG-E5-F17*, TG-E5-F18, TG-E5-F19, TG-E5-F20*, TG-E5-F21*, TG-E5-F22*, TG-E5-F23, TG-E5-F24, TG-E5-F25, TG-E5-F26, TG-E5-F27, TG-E5-F28, TG-E5-F40*, TG-E5-F41, TG-E5-F42, TG-E5-F43, TG-E5-F44, TG-E5-F81*, TG-E5-F82/A3. TG fractions, as well as the commercially available UA (Rotichrom ${ }^{\circledR}$, Karlsruhe, Germany) and camptothecin (CPT; Sigma-Aldrich) were diluted in $1 \mathrm{mM}$ dimethyl sulfoxide (DMSO; Sigma-Aldrich) stock solution at room temperature. Experiments were performed using $1 \mathrm{mg} / \mathrm{ml} \mathrm{TG}, 5 \mathrm{mg} / \mathrm{mg}$ UA and $5 \mathrm{mg} / \mathrm{ml} \mathrm{CPT}$.

Cell counting. The MTC-SK cells were seeded at a density of $2 \times 10^{5}$ cells/ml into 24-well plates (Sarstedt, Wiener Neudorf, Austria). The $T G$ fractions were added at $10 \mu \mathrm{g} / \mathrm{ml}$ or $25 \mu \mathrm{g} / \mathrm{ml}$, UA was added at 5, 10 and $20 \mu \mathrm{M}$ and equal quantities of DMSO were added to the control cells. The cell suspensions $(50 \mu \mathrm{l})$ were diluted in $10 \mathrm{ml}$ Casyton ${ }^{\circledR}$ (Roche Diagnostics, 
Vienna, Austria) and measured automatically four times using a Casy-1 Cell Counter \& Analyzer system (Model TTC; Schärfe System, Reutlingen, Germany).

Cell proliferation and viability. A 4-3-(4-iodophenyl)-2-(4-nitr ophenyl)-2H-5-tetrazolo-1,3-benzene disulfonate (WST-1) Cell Proliferation assay (Roche Diagnostics, Mannheim, Germany) was used to quantify the proliferation and viability, by measuring mitochondrial dehydrogenase, of the MTC-SK and HF-SAR cells. The MTC-SK cells were seeded into 24-well plates (Sarstedt) at a density of $2 \times 10^{5}$ cells $/ \mathrm{ml}$ at $37^{\circ} \mathrm{C}$ for 24 , 48 and $72 \mathrm{~h}$ in Ham's 12, supplemented with FBS, with either DMSO (control), 10 or $25 \mu \mathrm{g} / \mathrm{ml}$ of the different $T G$ fractions, or 5,10 or $20 \mu \mathrm{M}$ UA. A suspension of $100 \mu \mathrm{l}$ was transferred into 96-well plates. The HF-SAR cells were dissociated using trypsin/EDTA (Sigma-Aldrich) and seeded into 96-well plates at a density of $1 \times 10^{5}$ cells $(100 \mu \mathrm{l} /$ well $)$. Following adherence, the cells were treated with either DMSO (control), 10 or $25 \mu \mathrm{g} / \mathrm{ml}$ of the $T G$ fractions, or 5,10 or $20 \mu \mathrm{M} \mathrm{UA}$, and were cultured for 24,48 and $72 \mathrm{~h}$. WST-1 reagent (10 $\mu \mathrm{l})$ was subsequently added to each well, incubated for $2 \mathrm{~h}$ at $37^{\circ} \mathrm{C}$ and detected using a multiwell spectrophotometer ELISA reader (ThermOmax microplate reader; Molecular Devices, Sunnyvale, CA, USA) at a range between 450 and $650 \mathrm{~nm}$. The result of each experiment was the mean of six parallel samples.

Light microscopy. Images of the $T G$-treated cells and the controls were captured using a Nikon inverted microscope (Eclipse TE 300; Nikon, Tokyo, Japan) and a Nikon 12-bit CCD camera (Nikon). Staining with 4',6-diamidine-2'-phenylindole dyhydrochloride (DAPI) was performed following 24, 48 and $72 \mathrm{~h}$ incubation with the $T G$ or UA. The cells were fixed using methanol and the slides were centrifuged with cell suspensions in FlexiPERM 8-chambers (Heraeus, Hanau, Germany) at $300 \mathrm{x}$ g for $5 \mathrm{~min}\left(5 \times 10^{6}\right.$ cells/chamber). The slides were incubated in a moist chamber at room temperature for $20 \mathrm{~min}$ in diluted DAPI stock solution $(1 \mu \mathrm{g} / \mathrm{ml}$ calcium and magnesium free-phosphate-buffered saline; CMF-PBS) and washed with CMF-PBS. Images were captured using a Leica DFC 300 FX camera (Leica, Wetzlar, Germany).

Electron microscopy. The cells were treated with TG-E5-F28 or DMSO at a concentration of $10 \mathrm{mg} / \mathrm{ml}$. After $48 \mathrm{~h}$, the cells were centrifuged at $300 \mathrm{x}$ g for $5 \mathrm{~min}$ at room temperature and fixed in 3\% glutaraldehyde (Plano $\mathrm{GmbH}$, Wetzlar, Germany) diluted in $0.1 \mathrm{M}$ cacodylate buffer (Plano $\mathrm{GmbH}$ ) on ice for $24 \mathrm{~h}$. The cells were postfixed on ice overnight in $1 \%$ osmium tetroxide (Sigma-Aldrich) in $0.1 \mathrm{M}$ cacodylate buffer, processed by modified routine methods (23) visualized under an FEI Technai12 transmission electron microscope (FEI Europe, Eindhoven, Netherlands) equipped with a Gatan Bioscan CCD camera (Gatan, Munich, Germany).

Caspase assays. The MTC-SK cells were treated with 10 or $25 \mu \mathrm{g} / \mathrm{ml}$ of the different $T G$ fractions; 5, 10 and $20 \mu \mathrm{M}$ UA; DMSO or $5 \mu \mathrm{M}$ CPT in 24 -well plates. Following the incubation periods, $50 \mu 1$ of each cell suspension was transferred into a 96-well white plate (Nunc, Roskilde, Denmark). Caspase activity was quantified using Caspase-Glo ${ }^{\circledR}$ assays (Promega, Mannheim, Germany). The activities of caspase-2,
$-3 / 7,-6,-8$ and -9 were measured in the MTC-SK cells in each group. The Caspase-Glo ${ }^{\circledR}$ assays were performed, according to the manufacturer's instructions. Briefly, Caspase $\mathrm{Glo}^{\circledR}$ substrate was mixed with Caspase Glo ${ }^{\circledR}$ buffer $(50 \mu \mathrm{l} /$ well $)$ in a 96-well plate according to the manufacturer's instructions (Promega). The samples were agitated for $30 \mathrm{sec}$ and measured following a $1 \mathrm{~h}$ incubation at room temperature in the dark. To avoid cross reactions, $50 \mathrm{nM}$ Ac-DEVD-CHO inhibitor (Promega) was added to the samples prior to addition of the reagents in the caspase-2, -6 and -9 assays. The emitted light was measured using a Lucy2 Typ 18610 luminometer (cat. no. 186101036; Mediators PhL) and the values were analyzed. Ham's F12+FBS (10\%) medium was used as a blank control. Double measurements were obtained in each assessment.

Treatment of MTC-SK-xenografts in severe combined immune deficient (SCID) mice with TG-E5-F28 and UA. A total of 19 female SCID mice, aged 11 weeks (Division of Laboratory Animal Science and Genetics, Medical University of Vienna) were injected subcutaneously with $3 \times 10^{7}$ MTC-SK cells in $0.3 \mathrm{ml}$ PBS per mouse. The mice were housed in cages with filtered air, and ad libitum access to food and water (standard mouse diet; $\boldsymbol{\gamma}$-irradiated; ssniff Spezialdiäten $\mathrm{GmbH}$, Soest, Germany). After tumor volumes reached $100 \mathrm{~mm}^{3}$, the compounds were injected intratumorally and consisted of either $100 \mu \mathrm{g}$ TG-E5-F28 dissolved in $100 \mu \mathrm{l}$ DMSO in Hanks' balanced salt solution (HBSS; $\mathrm{n}=8$ ) or $100 \mu \mathrm{l}$ DMSO in HBSS $(n=5)$ every 5 days. The tumor size was measured over a period of 21 days. UA was administered to another group of MTC-xenografts and, at tumor volumes of $100 \mathrm{~mm}^{3}$, the compounds were injected intratumorally and consisted of either 20 mM UA dissolved in $100 \mu$ DMSO in HBSS $(n=10)$ or $100 \mu 1$ DMSO in HBSS $(n=10)$ every 5 days. As a negative control, five mice were left untreated. The observation period was 28 days. The tumor size was measured every 3 days using a sliding caliper and the volume was calculated.

$R N A$ extraction and reverse transcription $(R T)$. The MTC-SK cells were seeded at a density of $2 \times 10^{5}$ cells $/ \mathrm{ml}$ and treated with $20 \mu \mathrm{M}$ UA or DMSO (control). Following incubation for 1 or $4 \mathrm{~h}$, the cells were transferred into $50 \mathrm{ml}$ tubes (Sarstedt) and centrifuged for $10 \mathrm{~min}$ at $300 \mathrm{x} \mathrm{g}$. This procedure was performed three times. The total RNA was isolated using TRIzol Reagent ${ }^{\circledR}$ (Molecular Research Centre, Cincinnati, $\mathrm{OH}$, USA). The RNA concentration was determined using a Nanodrop ND-1000 spectrophotometer (NanoDrop ${ }^{\circledR}$ Biotechnology GmbH, Erlangen, Germany). The RNA (1 $\mu \mathrm{g})$ from each preparation were then reverse-transcribed using a High Capacity RNA to cDNA kit (Applied Biosystems, Carlsbad, CA, USA), according to the manufacturer's instructions.

Quantitative polymerase chain reaction ( $q P C R$ ). The relative gene expression of NEMO was analyzed using $\beta$-actin as a housekeeping gene. The following primers were used: NEMO, forward 5'-GTGAGCGGAAGCGAGGAATG-3' and reverse 5'-AACGGTCTCCATCACAATCT-3' and $\beta$-actin, forward 5'-CATGTACGTTGCTATCCAGGC-3' and reverse 5'-CTC CTTAATGTCACGCACGAT-3'. 
SYBR Green I fluorescence dye (BioRad Laboratories, Inc., Vienna, Austria) was used for detection, and $12.5 \mu 1$ iQ SybrGreen Supermix, $5.5 \mu 1$ RNAse-free water and $0.5 \mu l$ each forward and reverse primer $(0.2 \mu \mathrm{M}$ final concentration; $10 \mu \mathrm{M}$ stock) were mixed thoroughly in PCR tubes. Subsequently, $6 \mu \mathrm{l}$ cDNA (5 ng $\mu \mathrm{l} ; 1$ :10 dilution with nuclease-free water) from the UA or DMSO treated MTC-SK cells were added. The cDNA of the pooled RNA (UA+DMSO) was added to the master mix for each gene to create a standard curve. The following cycles were performed: $95^{\circ} \mathrm{C}$ for $3 \mathrm{~min}, 40$ cycles at $95^{\circ} \mathrm{C}$ for $10 \mathrm{sec}$, $60^{\circ} \mathrm{C}$ for $45 \mathrm{sec}, 72^{\circ} \mathrm{C}$ for $40 \mathrm{sec}, 95^{\circ} \mathrm{C}$ for $10 \mathrm{sec}$, followed by $55^{\circ} \mathrm{C}$ for $10 \mathrm{sec}$, and the condition for the melting curve being $55-95^{\circ} \mathrm{C}$ (increase of $0.5^{\circ} \mathrm{C} / 5 \mathrm{sec}$ ). The data were normalized using the expression of $\beta$-actin and the relative gene expression was assessed using the $\Delta \Delta \mathrm{Cq}$ method (24).

Statistical analysis. The mean, standard deviation and significance were calculated using a two-tailed unpaired Student's t-test. The experiments with UA were repeated three times, however, due to limited quantities of the fractions, the $T G$ experiments were only performed once. Statistical analysis was performed using Microsoft Office Excel 2003 (Microsoft Corporation, Redmond, WA, USA). $\mathrm{P}<0.05$ was considered to indicate a statistically significant difference.

\section{Results}

Treated MTC-SK cells reveal the antiproliferative effects of TG and UA. The initial screen revealed a reduction in the proliferation of the MTC-SK cells treated with TG-2 $(25 \mu \mathrm{g} / \mathrm{ml})$, according to the CASY ${ }^{\circledR}-1$ Cell Counter \& Analyzer and WST1 results. All the subfractions, which split from TG-2, exhibited significant antiproliferative effects following treatment for $72 \mathrm{~h}$ at a concentration of $25 \mathrm{~g} / \mathrm{ml}$. TG-E5-18, TG-E5-F19, TG-E5-F23, TG-E5-F41, TG-E5-F43 and TG-E5-F82/A3 exhibited no or little antiproliferative effects; TG-E5-F27 and TG-E5-F44 exhibited low, but significant, antiproliferative effects; and TG-E5-F24, TG-E5-F25, TG-E5-F26, TG-E5-F28 and TG-E5-F42 exhibited marked antiproliferative effects at $10 \mu \mathrm{g} / \mathrm{ml}$ following $72 \mathrm{~h}$ incubation. TG-E5-F28 was the subfraction with the highest antiproliferative effects in the MTC-SK cells compared with the MTC-SK cells treated with DMSO (Fig. 1A and B). The activity of several caspases were subsequently analyzed with this subfraction and under transmission electron microscopy. UA also exhibited a dose-dependent antiproliferative effect on the MTC-SK cells compared with those treated with DMSO (Fig. 1C and D).

Treatment with 10 and $25 \mu \mathrm{g} / \mathrm{ml}$ of seven of the $T G$ fractions, including TG-E5-F25, revealed a decrease in cell number and a reduction in the activity of succinate dehydrogenase in the MTC-SK cells over 3 days, whereas TG-E5-F24 and TG-E5-F25 caused no reduction in the activity of succinate dehydrogenase in the HF-SAR cells at a concentration of $25 \mu \mathrm{g} / \mathrm{ml}$ (Fig. 2A).

The MTC-SK cells treated with $10 \mu \mathrm{M}$ UA demonstrated a significant reduction in cell number following incubation for $48 \mathrm{~h}$ or following only $24 \mathrm{~h}$ incubation with $20 \mu \mathrm{M}$ UA. No antiproliferative effects were observed in the control. A significant reduction in the activity of succinate
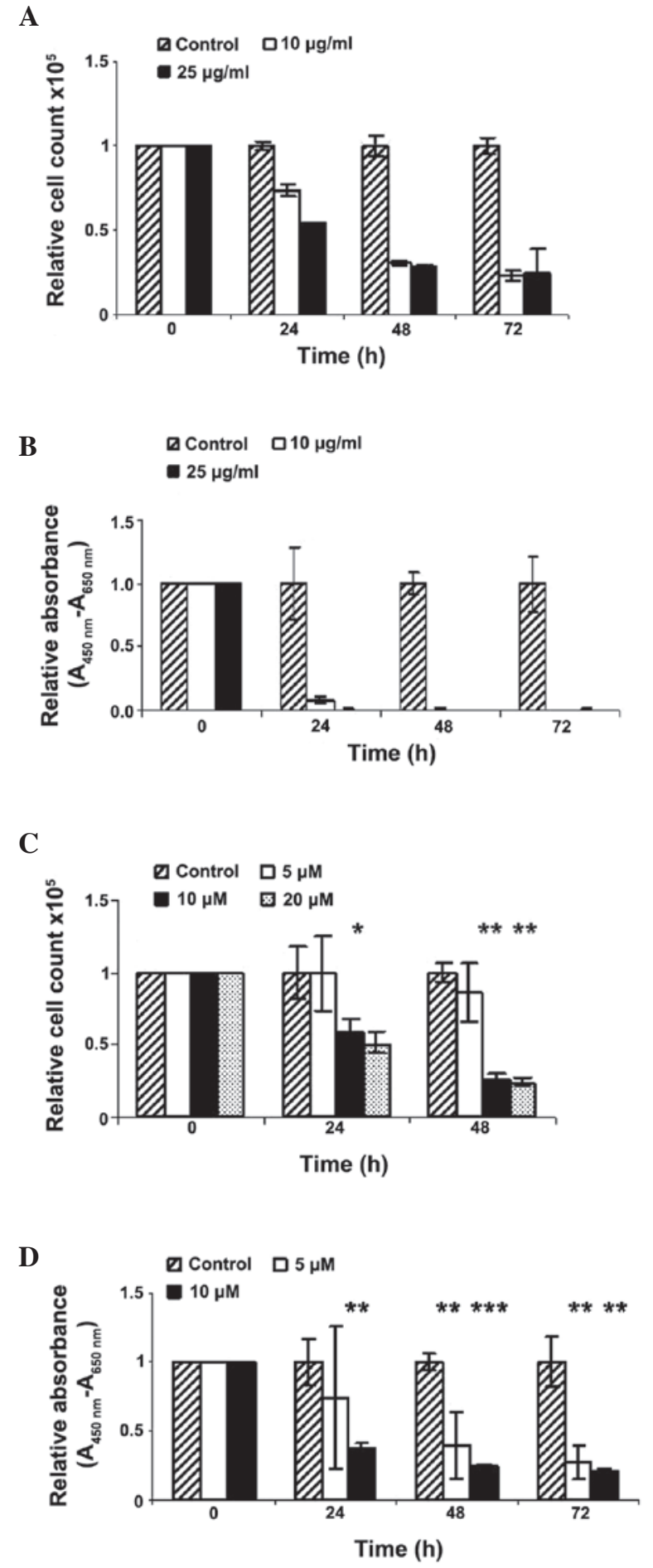

Figure 1. Antiproliferative effects of Trailliaedoxa gracilis and UA on MTC-SK cells. Cell proliferation was evaluated using a CASY ${ }^{\circledR}-1$ cell counter and analyzer, and viability was evaluated using a WST-1 assay of MTC-SK cells treated with (A and B) TG-E5-F28 or (C and D) UA for 24, 48 and $72 \mathrm{~h}$. The controls were treated with dimethyl sulfoxide. Data are expressed as the mean \pm standard deviation. ${ }^{*} \mathrm{P}<0.05,{ }^{* *} \mathrm{P}<0.01,{ }^{* * *} \mathrm{P}<0.001$, compared with control. UA, ursolic acid.

dehydrogenase was measured at a concentration of $20 \mu \mathrm{M}$ following incubation for $24 \mathrm{~h}$ (Fig. 2B).

Fractions of TG and UA damage MTC-SK cells. The MTC-SK cells treated with the majority of the screened $T G$ 
A

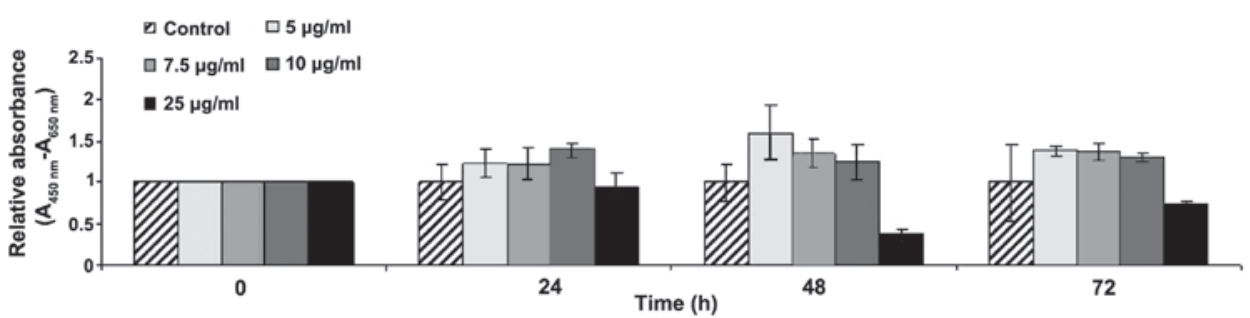

B

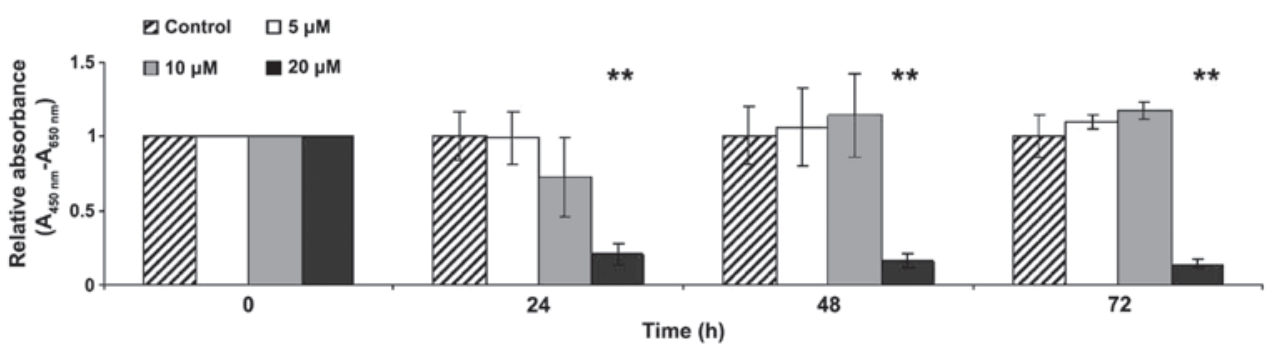

Figure 2. Effects of Trailliaedoxa gracilis and UA on HF-SAR cells. Cell viability was evaluated using a WST-1 assay on HF-SAR cells treated with (A) TG-E5-F25 or (B) UA for 24, 48 and $72 \mathrm{~h}$. The controls were treated with DMSO. Data are expressed as the mean \pm standard deviation. ${ }^{* *} \mathrm{P}<0.01$, compared with control. UA, ursolic acid.
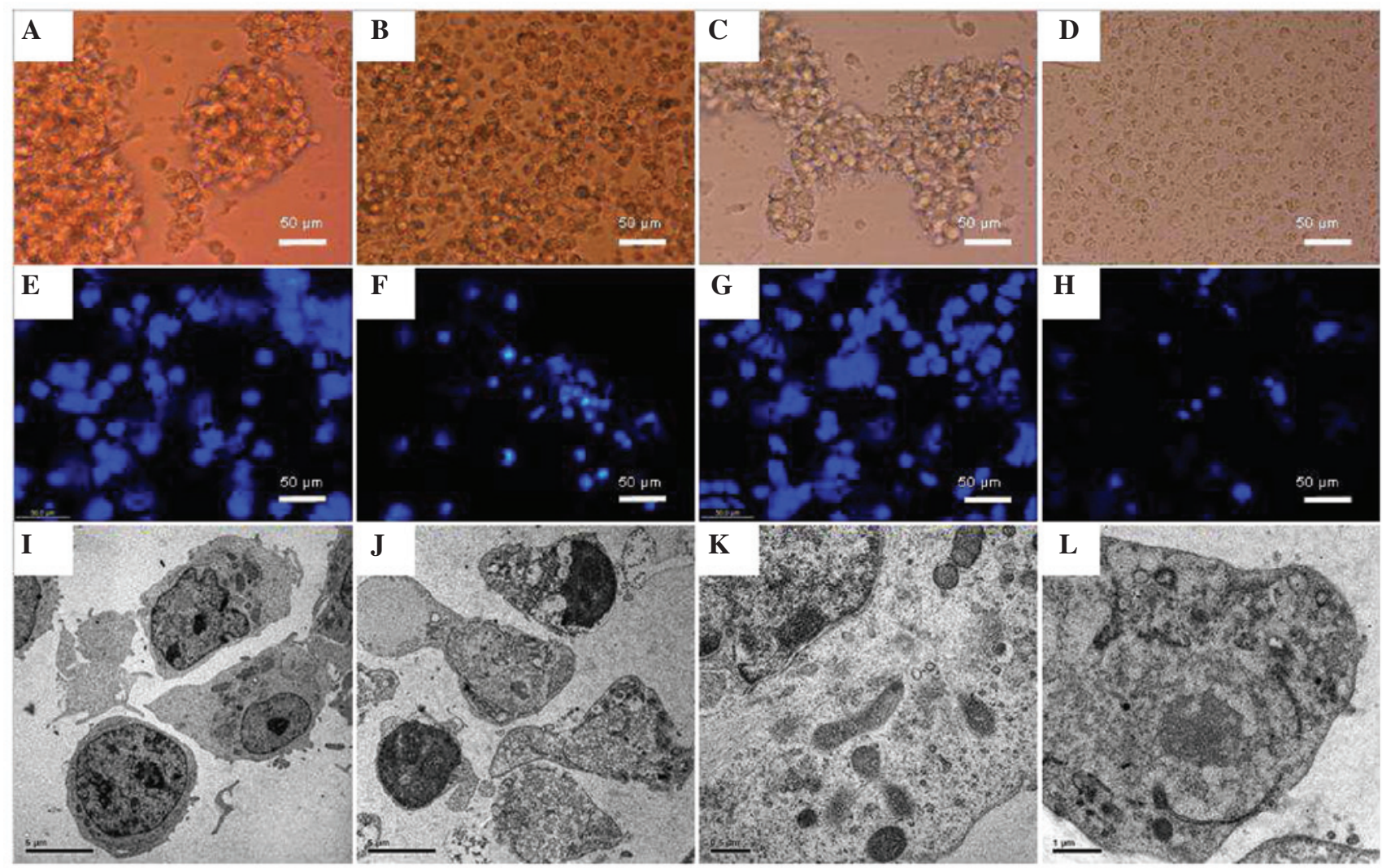

Figure 3. Morphology of the MTC-SK cells treated with $T G$ and UA. (A-D) Dissociation of cell aggregates following $24 \mathrm{~h}$ incubation (magnification, $\mathrm{x} 400$ ). (B) $10 \mu \mathrm{g} / \mathrm{ml}$ TG-E5-F25 and (D) $10 \mu \mathrm{M}$ UA. (E-H) Pro-apoptotic cell bodies and nuclei damage following $4 \mathrm{~h}$ incubation (magnification, $\mathrm{x} 400$ ). (F) $10 \mu \mathrm{g} / \mathrm{ml}$ TG-E5-F25 and (H) $10 \mu \mathrm{M}$ UA. (I-L) Structural damage and disintegration of clusters following $45 \mathrm{~h}$ incubation. (J and L) $25 \mu \mathrm{g} / \mathrm{ml}$ TG-E5-F25. (I and J) magnification, x3,100; (K) magnification, x13,300; (L) magnification, x20,000. (A, C, E, G, I and K) Respective controls treated with dimethyl sulfoxide. UA, ursolic acid; $T G$, Trailliaedoxa gracilis.

fractions and UA revealed altered morphology compared with the DMSO-treated control cells. A dissociation of cell aggregates was observed following incubation for $24 \mathrm{~h}$ (Fig. 3A-D). DAPI staining revealed that the MTC-SK cells treated with four of the fractions, particularly TG-E5-F25, exhibited pro-apoptotic cell bodies following incubation for $4 \mathrm{~h}$ (Fig. 3E and F), however, the majority of the fractions produced no specific pro-apoptotic cell bodies in the treated MTC-SK cells. The nuclei of the MTC-SK cells treated with either the $T G$ fractions or UA were damaged compared with the 
A

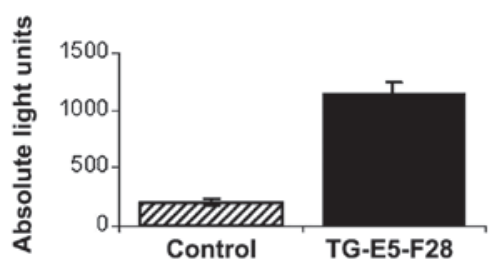

B

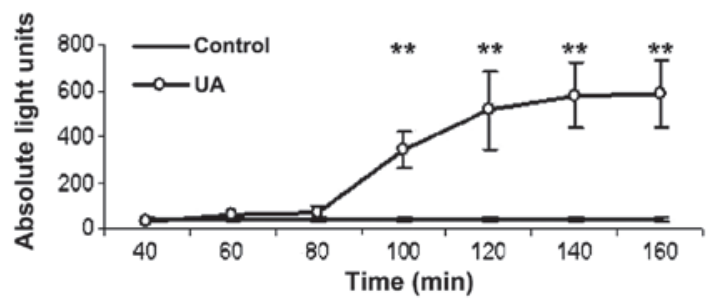

C

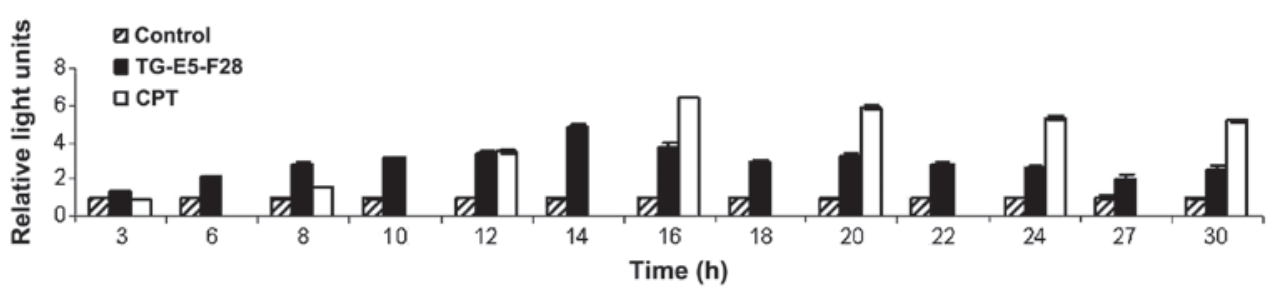

D

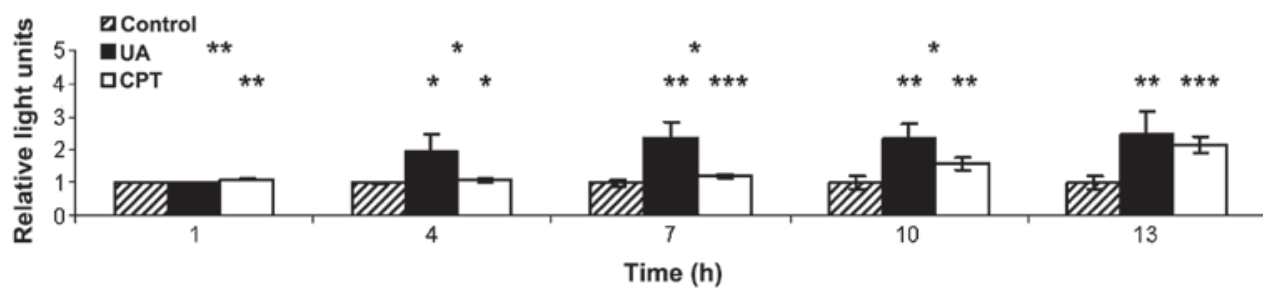

Figure 4. Apoptosis is activated in MTC-SK cells following treatment with Trailliaedoxa gracilis and UA. Caspase activity was evaluated using different caspase assays. (A and B) Activity of caspase-3/7 in MTC-SK cells following treatment with (A) TG-E5-F28 and (B) UA. (C and D) Activity of caspase-8 in MTC-SK cells following treatment with (C) TG-E5-F28 and (D) UA. Control cells were treated with dimethyl sulfoxide and CPT was used as a positive control. Data are expressed as the mean \pm standard deviation. ${ }^{*} \mathrm{P}<0.05,{ }^{* *} \mathrm{P}<0.01,{ }^{* * *} \mathrm{P}<0.001$, compared with control (upper ${ }^{*}$ and ${ }^{* *}$ indicate cells treated with UA compared with cells treated with CPT. UA, ursolic acid; CPT, camptothecin.

DMSO-treated MTC-SK cells (Fig. 3G and H). Transmission electron microscopy revealed structural damage and disintegration of clusters in the MTC-SK cells treated with TG-E5-F28 compared with the DMSO-treated MTC-SK cells. The heterochromatin/euchromatin structure was reduced, cell organelles were damaged and pro-apoptotic vesicles were observed.

$T G$ fractions and UA induce apoptosis in MTC-SK cells. The activity of caspase-3/7 increased significantly in the MTC-SK cells treated with TG-E5-F28 for $12 \mathrm{~h}$ compared with the DMSO-treated MTC-SK cells (Fig. 4A and B). The activity of caspase- 8 increased in the MTC-SK cells treated with TG-E5-F28 compared with the DMSO-treated MTC-SK cells (Fig. 4C) and the activities of caspase-2, -6 and -9 increased in the MTC-SK cells treated with different $T G$ fractions compared with the DMSO-treated MTC-SK cells. The activities of caspase-3/7 and -8 were significantly increased in the MTC-SK cells treated with UA compared with the DMSO controls (Fig. 4B and D).

Treatment with UA does not alter the expression of NEMO in MTC-SK cells. The RNA isolation and gel-electrophoretic separation of small RNA, 18S rRNA and 28S rRNA from the UA-treated and DMSO-treated MTC-SK cells was successful and was used to synthesize cDNA. $\beta$-actin was more stable compared with GAPDH when the cells were treated with UA. The expression of $\beta$-actin was used as a housekeeping gene (confirmed using GeneEx ${ }^{\circledR}$ software). The ratio of $N E M O$ and $\beta$-actin was calculated for each experiment: $1.2(\log 2$ :
$0.23), 0.8(\log 2:-0.32)$ and $0.5(\log 2:-0.98)$, suggested that the expression of $N E M O$ did not differ between the MTC-SK cells treated with UA or DMSO. Although the first experiment revealed a non-significant $(\mathrm{P}=0.502)$ increase in the expression of $N E M O$ in the cells treated with UA, the subsequent two experiments revealed a non-significant decrease $(\mathrm{P}=0.505$ and $\mathrm{P}=0512$, respectively) in the MTC-SK cell line treated with UA.

TG-E5-F28 and UA causes no inhibition of tumor tissues in MTC xenografts. The MTC-SK tumor-bearing SCID mice treated with TG-E5-F28 did not progress differently compared with the control mice. Following treatment for 1 week, the tumor volume in the mice treated with TG-E5-F28 decreased by $5.7 \pm 26.2 \%$ and decreased $11.4 \pm 24.1 \%$ after 2 weeks compared with the controls. Following treatment for 3 weeks, a $0.7 \pm 20.1 \%$ increase in tumor volume was measured compared with the controls. The P-values were 0.394, 0.294 and 0.483 for the first, second and third week of treatment, respectively. The MTC-SK tumor-bearing SCID mice treated with UA exhibited no difference in progression compared with the control mice, with P-values between 0.221 and 0.492 .

\section{Discussion}

The interest in medicinal herbs for the identification of novel drugs has increased in recent years. Extensive lists of plant extracts with health benefits have been compiled 
and are increasing (25). Active compounds, including curcumin, resveratrol and linalool, target apoptotic pathways and affect proteins, including STAT-1/3, NF- $\kappa$ B or B-cell lymphoma-2 (25). Investigating these pathways and their association with the effects of active plant compounds may provide insight into the role of different proteins in the apoptotic pathways.

The MTC-SK cell line represents a useful model for investigating anticancer agents. Our previous studies examined the effects of several plant extracts on MTC cell lines, including MTC-SK, SINJ, BOJO and SHER-I $(1,26,27)$. Plant extracts from Aglaia sp., Stemona tuberosa, Uncaria tomentosa and Cautleya gracilis (Smith) Dandy have been observed to induce apoptosis in MTC cell lines $(5,6,8,9)$.

Novel plant extracts have been assessed, not only in MTC cell lines, but also in other cell lines of neuroendocrine tumors, including KRJ-I, a NET of the small intestine (28). Different $T G$ fractions have pronounced apoptotic effects on KRJ-I cells in vitro and in vivo (7).

In the present study, each $T G$ subfraction demonstrated dose-dependent effects on the inhibition of cell growth and viability. All fractions caused a dose-dependent inhibition of the spheroidal structure, which is typical for the MTC-SK cell aggregates, however, pro-apoptotic bodies were only observed in a few fractions, including TG-E5-F24 and TG-E5-F25.

High levels of DMSO may activate other pathways, leading to false interpretation of results. Numerous cases of maturation and differentiation of cells treated with DMSO have been reported, including neuroblastoma cells, hepatocytes and mammary epithelial cells (29-31). Evaluation of the cytotoxic effects of DMSO on Caco2/TC7 cells revealed that a concentration of $\leq 10 \%$ DMSO does not impair cells (32). As the present study was performed with DMSO concentrations $<10 \%$, the solvent was not considered responsible for the effects observed in the MTC-SK cells.

Following the assessment of the fractions using a CASY®-1 Cell Counter \& Analyzer system and WST-1 cell viability assays, the most effective agents were selected and used for caspase-3/7 assays to determine whether the decrease in cell number and mitochondrial activity was associated with necrotic or apoptotic events caused by the $T G$ subfractions. The MTC-SK cells treated with these fractions (TG-E5-F24, TG-E5-F25, TG-E5-F26, TG-E5-F28 and TG-E5-F42) exhibited increased caspase-3/7 activity compared with the DMSO-treated control cells. The MTC-SK cells treated with TG-E5-F28 also exhibited increased activities of caspase-6 and pro-caspases-2, -8 and -9 .

The ultrastructure of the MTC-SK cells treated with TG-E5-F28 revealed severely damaged cells and an increase in vacuoles. The membrane structures were damaged and the nuclei exhibited altered homochromatin and heterochromatin, although pro-apoptotic bodies were not observed.

In the HF-SAR cells, no difference was observed between the control cells treated with DMSO or the cells treated with the TG-E5-F24 or TG-E5-F25 subfractions. The MTC-SK cells, which build spheroids in suspension, were seeded at a concentration of $2 \times 10^{5}$ cells $/ \mathrm{ml}$ and the HF-SAR cells were seeded at a concentration of $1 \times 10^{5}$ cells $/ \mathrm{ml}$, as they grow adherently. Therefore, although there were a larger quantity of plant extract relative to each HF-SAR cell, they were not impaired.

The results of the present study led to the hypothesis that $T G$ contains a pro-apoptotic agent that, in low quantity, caused MTC tumor cell death by activating the apoptotic pathway. How this activation is performed remains to be elucidated. Since caspase-2 was activated late, the highest levels of which were observed in the MTC-SK cells following $20 \mathrm{~h}$ incubation with TG-E5-F28, this caspase was excluded as an inducing factor for apoptosis. Caspase- 8 or -9 may have been responsible for the activation of the programmed cell death in the $T G$ fraction-treated MTC-SK cells. The initiator caspases induce apoptosis via the extrinsic or intrinsic pathway; the extrinsic pathway is initiated by ligation of a transmembrane death receptor of TNF receptor 1, while the intrinsic pathway is initiated by selective mitochondria permeabilization, which releases cytochrome $c$ into the cytosol (33). Since the extrinsic pathway involves caspase- 8 and the intrinsic pathway involves caspases- 2 and -9 , it is possible that the activation of apoptosis in the MTC-SK cells treated with TG-E5-F28 occurs via the extrinsic pathway.

The results from the present study are similar to those of Svejda et al (7), who performed comparable experiments on the KRJ-I NET cell line, which appear to be more sensitive to $T G$ fractions than MTC-SK cells.

UA was identified in all the $T G$ extracts, and was compared with the highly effective $T G$ fractions from the prior experiments. The present study therefore repeated the CASY ${ }^{\circledR}-1$ Cell Counter \& Analyzer system and WST1 cell viability assessments using the same concentrations of UA, TG-E5-F41 and TG-E5-F44. The results revealed a similar dose-dependent inhibition of cell proliferation in the MTC-SK cells treated with UA and $T G$. The MTC-SK cells treated with $10 \mu \mathrm{m}$ UA exhibited a significant decrease in cell number following treatment for $48 \mathrm{~h}$ and a significant decrease in the activity of succinate-dehydrogenase following incubation for $24 \mathrm{~h}$, compared with the DMSO controls. Destruction of cell clusters was observed in the MTC-SK cells treated with $5 \mu \mathrm{M}$ for $24 \mathrm{~h}$, and pro-apoptotic cell bodies were observed in the MTC-SK cells treated with 10 and $20 \mu \mathrm{M}$ UA. The initiator caspase- 8 and the effector caspase- $3 / 7$ were significantly activated in the MTC-SK cells treated with UA compared with the DMSO controls. It was deemed unlikely that UA functioned by inhibiting topoisomerase I, as the activation of caspases following treatment with CPT was always later compared with the treatment with UA. The activation of the effector caspase-3/7 in MTC-SK cells treated with UA was induced following incubation for $\sim 80-100 \mathrm{~min}$, which was important for determining the necessary incubation period for the qPCR.

Due to limitations on the small quantities of the $T G$ fractions, it was not possible to perform experiment more than twice to establish significant results. For qPCR analysis, larger quantities of treated cells were required to obtain a sufficient quantity of mRNA.

The gene expression of $N E M O$, involved in apoptosis, has received increasing attention in recent years. NEMO can affect upregulate or downregulate the apoptotic pathway and appears to be a highly conserved protein with different regulatory regions. It has four transcription start sites and two promoters, one located in the G6PD intron 2 and the other located in a $\mathrm{CpG}$ island (34). The most recognized apoptotic pathway is induced 
by TNF, however, the majority of cells are resistant to apoptosis via the NF- $\mathrm{B}$ pathway, in which the regulatory subunit NEMO is responsible for activation of the IKK complex. An extrinsic pathway of apoptosis is possible in the absence of NEMO activating caspase-8 (20). The results from the present study suggested that apoptosis occurred via the extrinsic pathway, therefore, whether there is an association between the expression of NEMO in the UA-treated MTC-SK cells was investigated.

Following incubation of the MTC-SK cells with $20 \mu \mathrm{M}$ UA or DMSO for $80 \mathrm{~min}$, the RNA was isolated and cDNA was synthesized to evaluate the quantity of $N E M O$, using $\beta$-actin as a housekeeping gene. Since none of the three experiment repeats revealed a significant difference in NEMO between the treated and control MTC-SK cells, it was hypothesized that UA did not affect the expression of NEMO.

UA inhibits the $\mathrm{NF}-\kappa \mathrm{B}$ activation pathway by inhibiting the IKK complex (35), which is associated with the expression levels of NEMO. Therefore, it was hypothesized that the expression of NEMO is altered in MTC-SK cells treated with UA. However, the results suggested that another activation pathway for IKK is involved, which is independent of the upregulation of NEMO. IKK inhibition can be explained with the CYLD and A20 deubiquitination enzymes and an inhibition of $\mathrm{K}$ ubiquitin proteins (36). CYLD inhibits vascular lesion formation by suppressing the activity of NF- $\kappa \mathrm{B}$ activity, however, it also demonstrates pro-inflammatory response in vascular smooth muscle cells (37). The downregulation of A20 appears to be associated with several types of cancer (38). These proteins suggest possible NEMO-independent regulation of the IKK complex. In addition, K63-linked chains are involved in the assembly of the IKK complex and K11 ubiquitin. These proteins are important for activation of the IKK complex to prevent apoptosis and to ensure the conformation of these proteins for an adequate interaction between themselves and the IKK complex (39).

The HF-SAR cells treated with UA at different concentrations demonstrated a marginal decrease in the activity of succinate-dehydrogenase following incubation with $10 \mu \mathrm{M}$ UA. However, following incubation for $72 \mathrm{~h}$, these cells recovered completely, exhibiting the same mitochondrial activity as the HF-SAR cells treated with DMSO. The cells treated with $20 \mu \mathrm{M}$ UA had significantly decreased succinate dehydrogenase activity in each measurement and the cells treated with $5 \mu \mathrm{M}$ UA revealed no difference in mitochondrial activity.

Despite the evidence that TG-E5-F28 and UA exhibited increased apoptotic effects in treated MTC-SK cells in vitro, the in vivo experiments revealed no reduction in tumor volume in MTC-SK-bearing SCID mice treated with these substances. Svejda et al identified a tendency towards tumor inhibition in KRJ-I-bearing SCID mice treated with TG-E5-F28, whereas MTC-SK cell-bearing SCID mice revealed no response. It was evident that the KRJ-I neuroendocrine tumor cells were more sensitive towards this drug than the MTC-SK medullary thyroid carcinoma cells.

The present study hypothesized that UA induced apoptosis in MTC-SK tumors, but that it was not present in sufficient concentrations to eliminate the tumor, enabling the surviving cells to proliferate and grow at the same speed as the tumors observed in the control mice. A higher concentration of UA in the tumor cells during weeks 3 and 4 of each experiment may have improved the results. The elimination of the substance through the kidneys and the liver may explain the absence of effects of UA and TG-E5-F28 in MTC-SK tumor-bearing SCID mice. However, if this were the case, the results of the previous study on TG-E5-F28-treated KRJ-I tumor-bearing SCID mice, would have been similar to those of the present study.

\section{Acknowledgements}

This study was supported by the Austrian Cancer Aid/Styria (no. EF 01/2004), the Franz Lanyar Foundation (Project no. 357) and the Jubilee Fund of the Austrian National Bank (Project no. 14394). The authors would like to thank Ms. Eugenia Lamont (Medical Editor and Translator, Medical University of Graz, Graz, Austria) for critically reviewing this manuscript, as well as Professor Sandra Wallner-Liebmann for providing the SYBR-Green I fluorescent dye, and Dr Robert Fuchs for his support using the Leica DFC 300 FX (Institute of Pathophysiology and Immunology, Center of Molecular Medicine, Medical University of Graz, Graz, Austria).

\section{References}

1. Pfragner R, Höfler $\mathrm{H}$, Behmel A, Ingolic $\mathrm{E}$ and Walser $\mathrm{V}$ : Establishment and characterization of continuous cell line MTC-SK derived from a human medullary thyroid carcinoma. Cancer Res 50: 4160-4166, 1990.

2. Herold G: In: Innere Medizin. Herold, Köln, 743-745, 2012 (In German).

3. Nicolini V, Cassinelli G, Cuccuru G, Bongarzone I, Petrangolini G, Tortoreto M, Mondellini P, Casalin P, Favini E, Zaffaroni N, Zunino F and Lanzi C: Interplay between Ret and Fap-1 regulates CD95-mediated apoptosis in medullary thyroid cancer cells. Biochem Pharmacol 82: 778-788, 2011.

4. Schulten HJ, Al-Maghrabi J, Al-Gahmdi K, Salama S, Al-Muhayawi S, Chaudhary A, Hamour O, Abuzenadah A, Gari M and Al-Qhatani M: Mutational screening of RET, HRAS, KRAS, NRAS, BRAF, AKT1 and CTNNB1 in medullary thyroid carcinoma. Anticancer Res 31: 4179-4183, 2011.

5. Li ZX, Sturm S, Stuppner H, Schraml E, Aguiriano-Moser V, Siegl V and Pfragner R: The dichloromethane fraction of Stemona tuberosa Lour inhibits tumor cell growth and induces apoptosis of human medullary thyroid carcinoma cells. Biologics: Targets and Therapy 1: 455-463, 2007.

6. Li Z, Sturm S, Svejda B, Höger H, Schraml E, Ingolic E, Siegl V, Stuppner H and Pfragner R: Anticancer activity of novel extracts from Cautleya gracilis (Smith) Dandy: apoptosis in human medullary thyroid carcinoma cells. Anticancer Res 28 (5A): 2705-2713, 2008.

7. Svejda B, Aguiriano-Moser V, Sturm S, Höger H, Ingolic E, Siegl V, Stuppner H and Pfragner R: Anticancer antivity of novel plant extracts from Trailliaedoxa gracilis (W.W. Smith \& Forrest) in human carcinoid KRJ-I cells. Anticancer Res 30: 55-64, 2010.

8. Rinner B, Siegl V, Pürstner P, Efferth T, Brem B, Greger H and Pfragner R: Activity of novel plant extracts against medullary thyroid carcinoma cells. Anticancer Res 24 (2A): 495-500, 2004.

9. Rinner B, Li ZX, Haas H, Siegl V, Sturm S, Stuppner H and Pfragner R: Antiproliferative and pro-apoptotic effects of Uncaria tormentosa in human medullary thyroid carcinoma cells. Anticancer Res 29: 4519-28, 2009.

10. Tappeiner J: Phytochemische Untersuchungen zu Trailliaedoxa gracilis, Diplomarbeit zur Erlangung des akademischen Grades Magistra der Pharmazie an der Leopold Franzens Universität Innsbruck, 15-50, 2007 (In German).

11. Handel-Mazzetti H: Naturbilder aus Südwest-China Erlebnisse und Eindrücke eines österreichischen Forschers während des Weltkrieges. Österreichischer Bundesverlag, Wien-Leipzig, p380, 1927 (In German).

12. Hao Wu, Liangqing Zeng and Xun Gong: Chromosome number of Traillaedoxa gracilis (Rubiaceae) endemic to jinsha river valley. Acta Botanica Yunnanica 32, 407-408, 2010. 
13. Pathak AK, Bhutani M and Nair AS: Ursolic acid inhibits STAT3 activation pathway leading to supression of proliferation and chemosensitization of human myeloma cells. Mol Canc Res 5: 943-955, 2007.

14. Liobikas J, Majiene D, Trumbeckaite S, Kursvietiene K Masteikova R, Kopustinkinene DM, Savickas A and Bernatoniene J: Uncoupling and antioxidant effects of ursolic acid in isolated rat heart mitochondria. J Nat Prod 74: 1640-1644, 2011.

15. Wu WY, Li J, Wu ZS, Zhang CL and Meng XL: STAT3 activation in monocytes accelerates liver cancer progression. BMC Cancer 11: 506, 2011.

16. Liu Q, Liu S, Shi Y, Li H, Hao J, Xing L, Cao Y and Duan H: Suppressors of cytokine signaling inhibit tubular, epithelial cell-myofibroblast transdifferentiation. Am J Nephrol 34: 142-151, 2011.

17. Li X, Massa PE, Hanidu A, Peet GW, Aro P, Savitt A, Mische S, Li J and Marcu KB: IKKalpha, IKKbeta and NEMO/IKKgamma are each required for the NF-kappa B-mediated inflamatory response program. J Biol Chem 277: 45129-45140, 2002.

18. Miyamoto S: Nuclear initiated NF- $\kappa \mathrm{B}$ signaling: NEMO and ATM take center stage. Rev Cell Res 21: 116-130, 2011

19. Rudolph D, Yeh WC, Wakeham A, Rudolph B, Nallainathan D, Potter J, Elia AJ and Mak TW: Severe liver degeneration and lack of NF-kappaB activation in NEMI/IKKgamma-deificient mice. Genes De 14: 854-862, 2000.

20. Legarda-Addison D, Hase H, O'Donnell MA and Ting AT: NEMO/IKKgamma regulates an early NF-kappaB-independent cell death checkpoint during TNF signaling. Cell Death Differ 16: 1297-1288, 2009.

21. Kojima H, Sasaki T, Ishitani T, Iemura S, Zhao H, Kaneko S, Kunimoto H, Natsume T, Matsumoto K and Kakajima K: STAT3 regulates nemo-like kinase by mediating its interaction with IL-6-stimulated TGFbeta-activated kinase 1 for STAT3 Ser 727 phosphorilation. Proc Natl Acad Sci USA 102: 4524-4529, 2005

22. Wolf C, Lederer K, Pfragner R, Schauenstein K, Ingolic E and Siegl V: Biocompatibility of ultra-high molecular weight polyethylene (UHMW-PE) stablized with alpha-tocopherol used for joint endoprotheses assessed in vitro. J Mater Sci Mater Med 18 1247-1252, 2007

23. Pfragner R, Behmel A, Ingolic E and Wirnsberger GH: Culture of human neuroendocrine tumor cells, In: Culture of Specialized Cells: Culture of human tumor cells. Pfragner R and Freshney RI (eds). John Wiley \& Sons, Inc., Hoboken, New Jersey, pp 373-403, 2004.

24. Pfaffl MW: A new mathematical model for relative quantification in real-time RT-PCR. Nucleic Acids Res 29: e45, 2001.

25. Aggarwal BB and Shishodia S: Molecular targets of dietary agents for prevention and therapy of cancer. Biochem Pharmacol 71: $1397-1421,2006$
26. Pfragner R, Wirnsberger G, Behmel A, Wolf G, Passath GA, Ingolic $\mathrm{E}$ and Adamiker D: New continuous cell line from human medullary carcinoma: SINJ. Phenotypic analysis and in vivo carcinogenesis. Int J Oncol 2: 831-836, 1993.

27. Pfragner R, Wirnsberger G, Ingolic E and Niederle B: Medullary thyroid carcinomas in cell culture - models for future therapies. Wien Klin Wochenschr 114: 279-283, 2002.

28. Pfragner R, Wirnsberger G, Niederle B, Behmel A, Rinner I, Mandl A, Wawrina F, Luo JS, Adamiker D, Höger H, Ingolic E and Schauenstein K: Establishment of a continuous cell line from a human carcinoid of the small intestine (KRJ-I): Characterization and effects of 5-azacytidine on proliferation. Int J Onc 8: 513-520, 1996.

29. Kimhi Y, Palfrey C, Spector I, Barak Y and Littauer UZ: Maturation of neuroblastoma cells in the presence of dimethylsulfoxide. Proc Nat Acad Sci USA 73: 462-466, 1976.

30. Mitaka T, Norioka K, Nakamura T and Mochizukio Y: Effects of mitogens and co-mitogens on the formation of small-cell colonies in primary cultures of rat hepatocytes. J Cell Physiol 157: 461-468, 1993

31. Rudland PS: Use of peanut lectin and rat mammary stem cell lines to identify a cellular differentiation pathway for the alveolar cell in the rat mammary gland. J Cell Physiol 152: 157-168, 1992

32. Da Violante G, Zerrouk N, Richard I, Provot G, Chaumeil JC and Arnaud P: Evaluation of the cytotoxicity effect of dimethyl sulfoxide (DMSO) on Caco2/TC7 colon tumor cell cultures. Biol Pharm Bull 25: 1600-1603, 2002.

33. Boatright KM and Salvesen GS: Mechanisms of caspase activation. Current Op in Cell Biol 15: 725-731, 2003.

34. Fusco F, Mercadante V, Miano MG and Ursini MV: Multiple regulatory regions and tissue-specific transcription initiation mediate the expression of NEMO/IKK $\gamma$ gene. Gene 383: 99-107, 2006.

35. Shishodia S, Majumdar S, Banerjee S and Aggarwaal BB: Ursolic acid inhibits nuclear factor- $\kappa \mathrm{B}$ activation induced by carcinogenic agents through suppression of IкBa kinase and p65 phosphorylation: correlation with down-regulation of cyclooxygenase 2, matrix metalloproteinase 9 and cyclin D11. Cancer Res 63: 4375-4383, 2003

36. Chen ZJ: Ubiquitination in signaling to and activation of IKK. Immunol Rev 246: 95-106, 2012.

37. Liu S, Lv J, Han L, Ichikawa T, Wang W, Li S, Wang XL, Tang D and Cui T: A pro-inflammatory role of deubiquitinating enzyme cylindromatosis (CYLD) in vascular smooth muscle cells. Biochem Biophys Res Commun 420: 78-83, 2012.

38. Wang Q, Yuan L, Liu Z, Jiang X and Lu J: Expression of A20 is reduced in pancreatic cancer tissues. J Mol Histol 43: 319-325, 2012.

39. Schmukle AC and Walczak H: No one can whistle a symphony alone-how different ubiquitin linkages cooperate to orchestrate NF-кB activity. J Cell Sci 125: 549-559, 2012. 